\title{
Asset Accumulation: an alternative approach to achieving the Millennium Development Goals
}

The United Nations Millennium Development Goals (MDGs) are unlikely to be achieved by 2015, due to conceptual flaws in their design as well as structural and political constraints faced during their implementation at the country level. While critique on the MDGs is widespread, innovative ideas on how to address these operational challenges are still scant. By reviewing several experiences in the world, including those of the Foundation for the Promotion of Local Development (PRODEL) in Nicaragua, and the Ministry of Cities in Brazil, this article highlights the importance of incorporating an asset accumulation perspective into MDGs related social policies and programmes as a way to generate an enabling environment that opens new opportunities for poverty reduction in cities of low- and middle-low income countries.

Key words: Millennium Development Goals, asset accumulation, poverty reduction, local development, international donors

\section{Introduction}

The United Nations (UN) Millennium Development Goals (MDGs) represent a path-breaking global effort to combat poverty and human deprivation. In comparison to prior attempts, the MDGs are specifically unique as they symbolise the first ever global long-term agreement to combat the multiple dimensions of poverty (UN Millennium Project, 2005; Sumner \& Tiwari 2009) while providing national and international policymakers with comprehensive and timebound goals, targets and indicators (Hulme, 2010).

Recent studies, however, stress that it is unlikely that all the MDG targets will be achieved by 2015 given a series of conceptual and operational constraints in their design and implementation strategies (Poku and Whitman, 2011; Vandemoortele, 2011). In many countries international donors and governments have not only failed to take into account the political, social and cultural dimensions of poverty (Cecchini and Notti, 2011), but also the more complex targets such as promoting gender equality or improving the lives of urban slum dwellers (Fukuda-Parr, 2010). 
While critique on the MDGs is widespread, innovative ideas on how to address these challenges are still incipient.

This article highlights the importance of incorporating an asset accumulation framework into the design and implementation of policies and programmes as a way to generate a better enabling environment that could open new opportunities for poverty reduction and therefore contribute to the overall achievement of the MDGs. The article starts by identifying the underlying approaches that led to the definition of the MDGs, as well as recent debates that highlight a number of limitations to their implementation. It then defines what an asset accumulation conceptual and operational framework is, and if it can be useful for the MDGs implementation. By reviewing how some countries are implementing the MDGs ${ }^{1}$, the paper shows the potential opportunities that experiences like the one of PRODEL in Nicaragua as well as the one of the Ministry of Cities in Brazil have for incorporating asset accumulation policies into poverty reduction strategies.

\section{Background}

The MDGs were predominantly influenced by two sets of concepts which guided international development theory and practice in the 1990s: human development and results-based management (Hulme, 2009). However, the way these ideas influenced the evolution of the MDGs has been mediated by various political and civil society based interests.

Acknowledging the failure of neoliberal structural adjustment policies and a general 'crisis of development' in the 1980s, the UN adopted a human development approach in the 1990s which was particularly shaped by the work of Streeten et al (1981), Nussbaum \& Sen (1993) and Sen (1999). This approach highlighted that human beings represented the end and the means of every development initiative and that poverty should be understood not as lack of income but as a multidimensional phenomenon of human deprivation. The approach contended that in order to lift people out of poverty, it was necessary to improve among others, their educational, health and nutritional capabilities and economic opportunities. The annual Human Development

\footnotetext{
${ }^{1}$ In preparation for this article a total of 56 documents relating to the MDGs were reviewed: 32 were policy strategies papers from international aid agencies (multilateral, bilateral, international non governmental organizations, as well as private philanthropy foundations); nine were Poverty Reduction Strategies Papers (PRSPs) from different countries; and 13 UNDP country reports.
} 
Reports (HDRs) produced by the United Nations Development Programme (UNDP), as well as the successive UN summits in the 1990s that explicitly addressed human development issues, provided the fundamental content of the MDGs (Hulme, 2010, Hulme and Scott, 2010).

Significant changes in the development agenda, with a major influence on the later MDGs, were also carried out by the Organisation for Economic Co-operation and Development's (OECD) Development Assistance Committee (DAC). In order to increase the flow of aid from donor countries, DAC launched in 1996 the report 'Shaping the $21^{\text {st }}$ Century: The Contribution of Development Co-operation' which offered a list of international development goals (IDGs) that reflected the particular interests of OECD member states' bilateral aid agencies. The IDGs were also strongly influenced by results-based management (RBM), an approach that aimed to improve processes of policy implementation with an explicit focus on outcome-based measurement. Moreover, IDGs policies were guided by certain goals, targets and indicators that had to be SMART (Specific, Measurable, Agreed, Realistic, and Time-limited) (Hulme 2010).

Following the launch of the IDGs, worldwide mobilisation on reducing global poverty increased significantly, and in 1998 the UN laid out its plan for a 'Millennium Assembly of the United Nations'. The then UN Secretary General saw the change of the millennium as a unique opportunity to address politically sensitive issues like poverty. In the following months international organisations, donor governments, governments of developing countries, and civil society organisations tried to shape the contents and the progress of the Millennium Assembly and incorporate those issues that they valued most into a final Millennium Declaration (Hulme, 2009; Hulme and Scott, 2010). ${ }^{2}$

These efforts led to the creation of the MDGs which were first outlined by the UN Secretary General report We the Peoples: The Role of the United Nations in the $21^{\text {st }}$ Century (Annan, 2000), and were then discussed by the 189 UN member states at the UN Millennium Summit on 8 September 2000, and approved as the Millennium Declaration in 2001. The MDGs consist of a set of eight goals, 21 targets (originally 18) and 60 indicators (originally 48) which were designed by the UN Secretary General in 2000 and updated by the 'Inter-Agency and Expert Group on the MDG Indicators' in 2005. Except for Target 7d which aims to improve the lives of

\footnotetext{
${ }^{2}$ For instance, a coalition of 40 governments in co-operation with civil society organisations and members of the Catholic Church formed the Jubilee 2000 movement which campaigned for Third World countries debt relief.
} 
100 million slum dwellers by the year 2020, all MDG targets should be fulfilled by the year 2015.

The MDGs have certainly led to a shift in the perceptions on poverty; from poverty as lack of income to poverty as a multidimensional phenomenon (Poku and Whitman, 2011; Vandemoortele, 2011). While their aim is to address the multiple dimensions of poverty, actual implementation has shown that not all MDGs targets are undertaken by national governments or international donors. For example, securing universal primary school enrolment is likely to be fulfilled by 2015 however more complex MDG targets such as empowering women or improving the lives of urban slum dwellers are rarely addressed (Fukuda-Parr, 2011).

According to different studies, these constraints were not coincidental but the result of logical contradictions intrinsic in the MDGs design. For example, the rights-based approach contends that the MDGs actually deal with a very limited body of social, economic, political and cultural rights and some targets do not correspond to human rights standards (Cecchini and Notti, 2011). Moreover, the MDGs not only miss the local and global structural causes of poverty such as discrimination or social exclusion (see Fischer, 2010; Saith, 2006) but they often are irrelevant to the situation of specific countries, or sub-regions within countries (Chibba, 2011). In addition MDG implementation is widely considered to be technocratic and 'top-down' and do not take sufficiently into account the voices and actions of the poor themselves (McGregor and Sumner, 2010). The need for a more contextualised and realistic MDG approach which is responsive to the actual needs and priorities of the poor is also stressed (Cecchini and Notti, 2011; McGregor and Sumner, 2010). Finally, there is a lack of legally binding accountability mechanisms that could secure a successful cross-country achievement of the MDGs (Gore, 2010).

\section{$3 \quad$ An asset accumulation framework fra $^{3}$}

With the probable exceptions of Cecchini and Notti (2011) that analyse the MDGs through the lens of a rights-based approach, and McGregor and Sumner (2010) who use a 3-D wellbeing approach to evaluate them, most studies have failed to base their MDG assessments on an

\footnotetext{
${ }^{3}$ This section draws on the asset accumulation framework developed by Moser (2009) as result of her longitudinal study of an urban poor community in Guayaquil, Ecuador, as well as recent urban participatory studies on the erosion of assets as a consequence of violence (Moser and McIlwain, 2004), and asset adaptation to climate change (Moser, Norton, Stein and Georgieva, 2010).
} 
explicit conceptual framework. Furthermore, current studies also seem to miss offering alternative policy guidelines that could help overcome the conceptual and operational constraints that impede MDG achievement. This paper tries to show how the incorporation of an asset accumulation framework into the MDGs strategies might help to overcome some of these limitations.

The concept of asset accumulation draws on theoretical and policy-focused literature on assetbased development approaches (see Sherraden, 1991; Carter and Barrett, 2006). Assets are defined as the "stock of financial, human, natural or social resources that can be acquired, developed, improved and transferred across generations" (Ford Foundation, 2004). Assets are not simply resources that people use to build livelihoods, they give people the capability to be and act (Bebbington, 1999). The acquisition of assets is not a passive act but one that creates agency and is linked to the empowerment of individuals and communities (Sen, 1997).

The concept of asset or capital endowments includes both tangible and intangible assets. The most widely known assets are natural (the stock of environmentally-provided assets); physical (the stock of plant, equipment, infrastructure, and other productive resources); social (the rules, norms, obligations, reciprocity, and trust embedded in social relations, social structures, and societies' institutional arrangements); financial (resources available to people, such as savings and credit); and human capital (investments in education, health and the nutrition of individuals; labour is linked to investments in human capital, health status determines people's capacity to work, and skills and education determine the returns from their labour). Assets can be both individual and collective in nature.

According to Moser (2009) an asset accumulation framework has two components:

- An asset index which is an analytical and diagnostic tool for understanding poverty dynamics and mobility. It quantitatively, or qualitatively, measures the accumulation or erosion of different assets over time and clarifies the interrelationship between different assets.

- An asset accumulation policy which is an associated operational approach that focuses directly on creating opportunities for poor people to accumulate and sustain complex asset portfolios.

Though an asset accumulation policy may include interventions that focus on strengthening individual assets, it is essentially a framework that provides an enabling environment with clear rules, norms, regulations and support structures to allow households and communities to identify 
and take advantage of opportunities to accumulate assets. To facilitate asset accumulation it is necessary to simultaneously address components at the following three interrelated levels:

- Structural level: Opportunities of asset accumulation are influenced by complex causal relationships between both external and internal structural factors and internal social processes - both of which require addressing.

- Institutional level: International, national and local public, private and civil society organisations are critical in providing an "enabling environment" for the accumulation of assets.

- Operational level: Assets are not static. In a changing global political, socioeconomic and environmental situation it is important to recognise their constant revalorisation, transformation, and renegotiation. Hence, at the operational level, an asset accumulation policy framework recognises prioritisation, sequencing, trade-offs, and negotiation potential, and combines a range of context-specific strategy options.

Finally, it is important to distinguish different stages or 'generations' of asset accumulation strategies (see Table 1). The first-generation is intended to access assets and focuses on the provision of 'basic needs' including water, roads, electricity, housing plots, improved health care and education and microfinance. Second-generation strategies are intended to ensure their further consolidation and prevent erosion - including the intergenerational transfer of assets. Thirdgeneration strategies, still very nascent, need to explore interventions that can maximise the linkages between different types of inter-dependent asset, thereby ensuring 'added value' and long-term sustainability.

Table 1: Aims and programmes of different asset generation strategies

\begin{tabular}{llll}
\hline & \multicolumn{1}{c}{ First generation } & \multicolumn{1}{c}{ Second generation } & \multicolumn{1}{c}{ Third generation } \\
\hline Policy aims & $\begin{array}{l}\text { Accessing an asset } \\
\text { portfolio }\end{array}$ & $\begin{array}{l}\text { Consolidating assets and } \\
\text { preventing erosion }\end{array}$ & $\begin{array}{l}\text { Maximising linkages between } \\
\text { interdependent assets }\end{array}$ \\
$\begin{array}{l}\text { Type of } \\
\text { programme }\end{array}$ & $\begin{array}{l}\text { Provision of land, } \\
\text { housing, basic } \\
\text { services and } \\
\text { infrastructure and } \\
\text { microfinance }\end{array}$ & $\begin{array}{l}\text { Citizen rights and security, } \\
\text { good governance and } \\
\text { accountability, including } \\
\text { intergenerational transfer of } \\
\text { assets }\end{array}$ & $\begin{array}{l}\text { Securing long-term financial and } \\
\text { institutional sustainability of agencies, } \\
\text { economic growth, permanent employment } \\
\text { and income }\end{array}$ \\
\hline
\end{tabular}

Source: Based on Moser (2009) 


\section{$4 \quad$ Implementing the MDGs}

This section tries to answer two questions. First, how are assets implicitly or explicitly incorporated in MDG-related policies and programmatic interventions? Second, what are national governments and international donors doing to achieve the MDGs?

Although the MDGs targets follow a multidimensional conceptualisation of poverty and address different vulnerabilities and forms of human deprivation, 'assets' are not explicitly mentioned, or incorporated in their design. However, when linking the MDGs targets to an assetbased index it is evident that 19 out of 21 MDG targets can be associated with one particular type of asset (Targets $8 \mathrm{~b}$ and $8 \mathrm{c}$ cannot be linked to specific assets as they are formulated to meet the needs of particular countries). Overall, about 57 per cent of the MDG targets (12 out of 21) refer to strengthening human capital such as education, health or nutrition; 14 per cent to financial capital such as income; 9 per cent to natural capital; and 9 per cent to physical capital. None, however, implicitly refers to the need to strengthen social capital.

The MDGs do not represent a policy paradigm but rather a normative framework of goals, targets, and indicators which should be addressed through different policy mechanisms by international and national stakeholders (Gore, 2010; Jahan, 2010). While the UN institutions, in particular UNDP, primarily monitor the overall MDG achievement in different member countries, their implementation is mainly coordinated by national governments and, to a smaller extent, by multilateral and bilateral development agencies, international non-governmental organisations (INGOs), and private foundations.

Ten years after the launching of the 'Millennium Declaration' the MDGs are far from being achieved successfully in practice (Vandemoortele, 2011). Many donor governments like the United States of America, Germany, the United Kingdom or Japan have not increased their Official Development Assistance (ODA) to 0.7 per cent of their overall Gross Domestic Product GDP, a goal established in MDG 8. Hence, aid flows which could facilitate developing countries' attempts to reduce poverty still remain limited (UNDP, 2010b). While emerging middle-income countries like Brazil, China and India are getting closer to a cross-target MDGs achievement, progress remains limited in the majority of least developed countries, especially in Sub-Saharan Africa (Fukuda-Parr, 2010; UNDP, 2010b).

The majority of national governments have incorporated the MDGs within their overall policy agenda. For example, there hardly exists a country Poverty Reduction Strategy Paper (PRSP) 
which does not explicitly refer to achieving the MDGs (Fukuda-Parr, 2010). Yet, when taking a closer look at national policy strategies, programmes, and interventions it is possible to identify how different countries emphasise some MDGs over others (Gore, 2010; Jahan, 2010). In an analysis of 22 PRSPs, Fukuda-Parr (2010) concludes that the majority of national governments fail to address complex MDGs like empowering women or improving environmental sustainability but prefer to address single issues like improving primary schooling, income poverty, water and sanitation and healthcare services in their policy agendas. Mitlin (2004) also found that critical issues required for urban poverty reduction, such as access to affordable and adequate land, housing finance, and basic infrastructure and services for slum dwellers were lacking in 23 PRSPs drafted by governments with international donors' support.

A desk review of 24 PRSPs and UNDP country reports undertaken by the authors of this article revealed that the majority of national governments primarily focus on targeting single sector issues like improving water and sanitation; nutrition; education or healthcare services. In this sense, most governments aim to achieve the MDGs through first generation asset accumulation strategies that focus on the provision of social and economic infrastructure.

Moser (2009) suggests, however, that providing access to an asset does not per se strengthen and consolidate the asset-base of the poor in the long term. For example, the government of Benin invested heavily in primary school infrastructure projects to significantly increase primary school enrolment rates and therefore was able to achieve MDG 2 already in 2008 (Republic of Benin, 2008; UNDP Benin, 2008). Bearing in mind that in 1980 only 68 per cent of children were enrolled in schools this represented a significant achievement. However, the increase in primary school enrolment did not necessarily lead to an overall improvement in the quality of education levels (UNDP Benin, 2008). Contrary to Benin, the government of Bolivia improved the quality of education by improving the capacity of its teaching system, and in Tanzania, the government addressed food security by increasing capital productivity through the introduction of new technologies and human capital strengthening in agriculture (UDAPE, 2008; United Republic of Tanzania, 2008).

Although increased numbers of children completing primary education and well-trained teachers in order to secure a high quality education are important, these are not per se changing poverty dynamics. In certain contexts, particular local structural and institutional constraints can harm the (educated) poor's opportunities to further accumulate assets (Moser, 2009). For 
instance, due to the lack of formal employment opportunities, many young people in developing countries fall into unemployment after completing their school education and continue to be trapped in poverty (Saith, 2006; UNDP, 2010b).

In many societies institutionalised discriminatory and exclusionary practices trap certain groups of people (based upon their race, ethnic origin, and place of residence or gender) into poverty (Kabeer, 2000; Hickey and du Toit, 2006). Put differently, even though every person might have completed primary education, institutionalised exclusionary practices can potentially hinder some societal groups from further accumulating assets, e.g. through denial of citizenship rights or denial of access to labour, and hence pull them back into poverty (Moser, 2009). In this sense, South Africa has gone further and promoted policies in which the assets of the urban poor have been consolidated by strengthening their rights through massive land tenure and titling processes, and increased participation of local municipalities, private stakeholders, civil society organisations and slum-dweller federations in the design and delivery of infrastructure and housing (Satterthwaite, 2006).

Few national governments of developing countries, however, rely on third-generation asset accumulation strategies that are able to maximise the linkages between inter-dependent assets. In summary, the majority of national government policies still focus on first-generation asset accumulation strategies; and although more governments are beginning to be aware of the need to establish strategies aimed to consolidate and prevent asset erosion, possibly, very few are trying to establish long-term strategies that will reinforce and maximise the linkages between different inter-dependent assets in a sustainable manner.

Today, almost every international donor organisation (be it a multilateral or bilateral agency or private international foundation) incorporates the MDGs within their policy agendas. Yet, in practice, they prioritise some MDGs over others according to their traditional poverty reduction agenda (Hulme and Scott, 2010; Sparr and Moser, 2007; Vandemoortele, 2011). A desk review of the MDG policy strategies of 32 international donors undertaken by the authors of this article revealed that the majority rely on first-generation asset accumulation strategies that aim to strengthen the human, physical and financial capital assets of the poor.

Overall, first-generation (accessing and asset portfolio) and second-generation (consolidating and preventing erosion) asset accumulation strategies are generally well understood among the different international donors. For instance, the ILO campaign 'Decent Work for All' aims to 
provide the poor with access to formal employment (human capital) (ILO, 2008). Similarly, the World Bank's 'Education for All' strategy emphasises the need to generate access to education (human capital) for the poor as well as generating sound policies for improving the educational quality of the primary system (Bruns et al, 2003). The Sector Wide Approach Programmes (SWAP) that international donors have tried to implement are an attempt address institutional constrains by improving the capacities of national governments to plan, design and implement more sustainable sector policies (Anson and Pfaumann, 2006). Likewise, private donors like the Rockefeller Foundation focus on providing the poor with access to healthcare services (human capital) while also working for the introduction of mechanisms directed to consolidate policies aimed to improve healthcare services (Rockefeller Foundation, 2003).

Yet, the majority of international donors still find it difficult to depart from different single issue policy strategies and rarely introduce more holistic policy approaches to maximise the linkages between assets in order to achieve multiple or more complex MDGs. In this context, the work, for example, promoted by Cities Alliance represents an interesting approach as it aims to improve the lives of urban slum dwellers and recognises the importance of addressing the local specifics that characterise slums in different regional settings by cooperating with local public,

private and civil society organisations to create a needs-based policy approach through an enabling local, structural and institutional environment. For example, they not only encourage slum dwellers to participate in local policy processes, but also work with local governments to develop new approaches that allow them to work with slum dwellers in programmes that go beyond the traditional slum upgrading schemes (Cities Alliance, 2005).

\section{Global Constraints}

To achieve the MDGs by 2015, it is also important to address both local and global structural constraints which adversely affect the asset-base of the poor (Fischer, 2010; McGregor and Sumner, 2010; Saith, 2006; Satterthwaite, 2003; UNDP, 2010a). While the impact of local structural constraints - such as institutionally manifested patterns of exclusion - remain hardly recognised within MDGs related policy discourses (Satterthwaite, 2003), national governments and international donors are increasingly becoming aware of the adverse impact of global 
structural constraints such as climate change, economic crises, internal conflicts and international migration flows on the overall possibility of achieving the MDGs (UNDP, 2010b).

In the September 2010 'UN Summit on Achieving the Millennium Development Goals' all member countries agreed on addressing climate change in MDGs related policy as follows: “.... climate change poses serious risks and challenges to all countries. We commit to address climate change in accordance with the principles and provisions of the United Nations Framework Convention on Climate Change, including the principle of common but differentiated responsibilities and respective capabilities" (UN 2010: 6). While agreements on addressing climate change are made, practical MDGs related policy initiatives that incorporate this issue remain scarce although certain programmes in some countries are trying to find innovative ways to do this (Saith, 2006; UN, 2010).

An example of such a programme is the Cambodia Climate Change Alliance (CCCA). ${ }^{4}$ In recent years, floods, erratic patterns of rainfall and droughts severely reduced the agricultural output of rural farmers (who represent 80 per cent of the population). This led to increased problems of food security and therefore hampered the achievement of MDG 1 (reducing extreme poverty and hunger). In order to cope with severe weather phenomena, the Cambodian government in cooperation with international development partners like Sida and UNDP formed the CCCA which aims to help local communities in developing resilience against recurring climate-related hazards, and to incorporate the issues of mitigation and adaptation in the national government agenda. The CCCA emphasises the need to implement cross-sector strategies that involve multiple national ministries and local stakeholders.

\section{Incorporating an asset accumulation framework into MDGs}

Incorporating an asset accumulation framework into MDGs related policies, programmes and interventions is fruitful in two ways. First, it can be used to assess the potential strengths and weaknesses of current MDGs related policies. As already shown, almost every national policy initiative implicitly aims to provide the poor with access to a reduced number of assets while also expecting that other assets will be accessed as a result of these interventions. That is why the majority of governments opt to address single MDGs and they do it quite successfully. However,

\footnotetext{
${ }^{4}$ For more information see http://www.un.org.kh/undp/what-we-do/projects/cambodia-climate-change-alliance
} 
most policy and programmatic interventions fail to recognise the linkages between different types of asset and, furthermore, fail to take into account potential local structural and institutional constraints which adversely affect the poor's asset-base and hence hamper the overall MDG achievement (Saith, 2006; UNDP, 2010a). Finally, the incorporation of an asset accumulation framework into MDGs related policy strategies represents an opportunity to overcome these constraints and also to look positively on how cross-target MDGs can be achieved

\subsection{Maximising the linkages between interdependent assets}

Single MDG targets do not stand in isolation from other MDG targets; rather, all MDG targets stand in an interdependent relationship (Fukuda-Parr, 2010; Saith, 2006). For example, in order to facilitate people's chances to access the formal labour market (MDG 1b) people need to have good health (MDG 4, 5, 6) and be sufficiently educated (MDG 2, 3). Following these ideas, global poverty can only be solved when its multiple dimensions are addressed simultaneously (UNDP, 2010b).

By conceptualising poverty as a dynamic phenomenon an asset accumulation framework highlights that it is not enough to incrementally generate access to and secure the consolidation of single assets. Instead, it emphasises the need to maximise the linkages between different interdependent assets (third-generation asset accumulation) not only to avoid an erosion of the overall asset-base of the poor in the long term, but to make the consolidation process sustainable in time (Moser, 2009).

Practical examples reveal that policy strategies which follow these ideas are particularly successful in reaching a cross-target MDG achievement. For instance, to help extremely poor people to escape less-than-one-dollar-a-day poverty (MDG 1a), the programme 'Targeting the Ultra Poor' (TUP) implemented by Bangladesh's NGO BRAC provides access to multiple assets and simultaneously generates an enabling structural and institutional environment which protects the poor from asset erosion and, meanwhile, provides them with opportunities to further accumulate other assets. Besides an explicit focus on targeting the observable outcomes of extreme income poverty, e.g. TUP participants are provided with monthly stipends (improving financial capital) and direct food and medicine transfers (improving human capital). TUP also aims to enhance the capabilities of its participants, e.g. though income generation training, health 
campaigns and literacy training (improving human capital), to empower them. Furthermore, through the creation of village assistance committees consisting of BRAC members, municipality officials and programme participants, TUP connects local political stakeholders with the extreme poor. TUP strengthens community ties and trust (improve social capital) by creating a supportive and responsive political environment that enables the poor to further accumulate other assets. In sum, although TUP addresses MDG 1 it pays attention to achieving other MDGs. Furthermore, it introduces policy mechanisms which intend to reduce the probability of backlashes in MDG achievements (Hulme and Moore, 2007).

\subsection{The importance of local context: generating an enabling environment}

The MDGs represent a global agenda on the reduction of global poverty. Yet, poverty itself is a phenomenon which is primarily experienced at the local level (Satterthwaite, 2003). Therefore, a MDGs related policy or programmatic intervention is only successful when it takes into account the particular context and the specifics of poverty in concrete localities (McGregor and Sumner, 2010). Although clearly constrained or potentiated by external structural, institutional and organisational factors, an asset accumulation framework views poverty as a subjective, relational and context-specific concept, in which the poor are seen as central agents to be in command and control of their own asset-base (Moser, 2009). Thus, involving the poor in MDGs related policies and programmes is indispensable as they can express more precisely their desires and needs to be incorporated into a poverty reduction policy and also make policy makers more responsive and accountable to their local priorities (World Bank, 2001).

The case of PRODEL in Nicaragua illustrates the importance of these participatory processes to achieve the MDGs at local level (Stein, 2010). Since 1994, action micro planning practices have been tested and institutionalised in a local development programme to access and transform urban poor community and household physical assets, as well as financial and productive assets of small businesses in Nicaragua, with strong participation from community based organisations (social capital) and the support from international agencies and formal multilateral banks, national government, local governments as well as microfinance institutions. This resulted in the development of a series of institutionalised financially sustainable instruments that changed the approaches and working methods of local governments, national agencies, and financial 
institutions towards the urban poor. Within the framework of the Local Development Foundation (PRODEL), more than 700 small infrastructure and basic service projects (water, sewerage, street, community centres, elementary schools, risk-mitigation works against natural disasters, etc.) were implemented in 11 secondary cities in Nicaragua, the majority in poor urban neighbourhoods, and mobilised more than US\$ 18 million in local contributions during a period of 15 years; more than 35,000 houses were improved through small and repetitive loans worth more than US\$ 45 million; and more than 22,000 small entrepreneurs improved their economic activities through more than 100,000 micro credits worth US $\$ 44$ million (Stein, 2010). The basic idea behind the PRODEL rationale is that the urban poor manage a portfolio of assets that can be leveraged, increased and also accumulated when external resources and opportunities are available. What is more significant is that the institutional setting of the programme not only remained but was institutionally transformed into an autonomous foundation (PRODEL) which today is financially self reliant and self sufficient, and has the capacity to steer resources to achieve cross-target MDGs at the local level in different municipalities.

Brazil's 'Cities for All' strategy is another example of what a country of such territorial dimensions and social complexities can do to sustain MDGs achievements in urban areas in the long term. The "Cities for All" Strategy, advocated by the Brazilian national Ministry of Cities ${ }^{5}$, relies on a holistic city development strategy which highlights the importance of responding to the needs and demands of the urban poor (Ministry of Cities Brazil, 2004). Due to the scarcity of national and regional financial and technical resources the strategy emphasises the need for national and municipal public, private and civil society based stakeholders to cooperate in improving the living conditions of poor urban slum dwellers. In order to respond to their specific needs it calls for the inclusion of slum dwellers in every stage of the urban development planning process. Furthermore, slum upgrading policies, in order to be more cost efficient and sustainable, are intended to acknowledge and build upon the already realised and planned investments of the urban poor themselves. The main objectives of the 'Cities for all' strategy are: facilitate housing improvements for low-income households (physical capital), secure land tenure and improve urban land rights (physical and environmental capital), improve basic services and urban infrastructure (human and physical capital), generate a healthy living environment (human

\footnotetext{
${ }^{5}$ The Ministry of Cities was founded by Brazil's former president Luis Ignacio Lula da Silva and it aims to integrate and link policies concerning urban development, housing, environmental health, mobility and urban transportation in the different cities of the country (Ministry of Cities Brazil 2004).
} 
capital), build community trust (social capital), encourage community participation, and generate pro-poor and responsive municipal institutions (Ministry of Cities Brazil, 2004).

The case of São Paulo illustrates how the 'Cities for All' strategy can be implemented successfully in practice (Budds and Teixeira, 2005). In 2003 São Paulo’s Municipal Secretariat of Housing and Urban Development (SEHAB) introduced a new urban development approach which is influenced by the 'Cities for All' strategy. It focuses on housing improvements while simultaneously providing infrastructure and public services, including leisure facilities and space for commercial units. SEHAB strongly encourages private sector and citizen involvement in all its projects. For instance, in order to increase the responsiveness to the needs of citizens SEHAB introduced public participation in all stages of its municipal policy. Through introducing an integrated and participatory urban development approach SEHAB contributed to large scale urban poverty reduction: by 2005 300,000 low-income households had already benefited through SEHABs new urban development approach, an example of a cross-target MDG achievement in São Paulo (Budds and Teixera, 2005). In MDG terms, the 'Cities for All' strategy which is currently implemented in São Paulo and other Brazilian cities aims to achieve MDG 7d by simultaneously tackling the other MDGs. Furthermore the strategy aims to generate a structural, institutional (by strengthen municipal institutions), and operational (ensuring long term programme financial and technical sustainability) environment which enables the poor to sustain their asset-base, accumulate further assets and to maximise the linkages between different interdependent assets.

\section{Conclusions}

This article assessed the MDGs and their related policy and programmatic interventions through the lens of an asset accumulation framework. In line with current research, it shows that the majority of governments in developing countries, and to a large extent, the international donors that support them, tend to address the MDGs on a single issue basis approach which prioritises improving primary schooling and healthcare services (human capital), income poverty (financial capital), water and sanitation (physical and human capital), and to a smaller extent access to land (natural capital), in their policy agendas. The analysis illustrates that neither the MDGs targets nor indicators explicitly or implicitly incorporate the concept of social capital. This narrow sector 
approach constraints the possibility of addressing more complex MDGs targets like empowering women, or improving the lives of urban slum dwellers, as well as the feasibility of reducing poverty on a long-term sustainable manner.

The article provides examples of governments, donors and NGOs that are trying to achieve the MDGs by moving from what this paper calls policies that ensure 'access to assets', to more comprehensive policies that aim to 'consolidate and protect the erosion of the assets' of the poor. Equally, it shows the importance of considering the adverse impact that structural constraints like climate change, the global economic crisis, and regional and local conflicts have in achieving the MDGs. Finally, the article shows that achieving the MDGs requires rethinking which policies and strategies can create an enabling environment that opens new opportunities for the poor. This involves translating the MDGs related policies into transformative local strategies that take into account the specific needs of the poor, not only by listening to their voices, but more importantly, by understanding which structural, institutional and operational measures could maximise the linkages of the interdependent assets that the poor command and control.

\section{References}

Annan, KA. (2000) We the Peoples: The Role of the United Nations in the 21st Century. New York: United Nations Department of Public Information.

Anson, R. and Pfaumann, P. (2006) 'The role of the sector-wide approach to sustainable rural development in Central America', RUTA Working Paper 20. Available: www.donorplatform.org/load/9794.

Bebbington, A. (1999) 'Capitals and Capabilities: A Framework for Analyzing Peasant Viability, Rural Livelihoods and Poverty', World Development 27(12): 2021-44.

Bruns, B., Mingat, A. and Rakotomalala, R. (2003) Achieving Universal Primary Education by 2015: A Chance for Every Child. Washington: World Bank.

Budds, J. and Teixeira, P. (2005) 'Ensuring the right to the city: pro-poor housing, urban development and tenure legalization in Sao Paulo, Brazil', Environment \& Urbanization 17(1): 89-113.

Carter, MR. and Barrett, CB. (2006) 'The Economics of Poverty Traps and Persistent Poverty: An Asset-Based Approach', Journal of Development Studies 42(2): 178-99. 
Chibba, M. (2011) 'The Millennium Development Goals: Key Current Issues and Challenges', Development Policy Review 29(1): 75-90.

Cecchini, S. and Notti, F. (2011) 'Millennium Development Goals and Human Rights: Faraway, so Close?', Third World Quarterly 12(1): 121-133.

Cities Alliance. (2005) Cities Alliance in Action. Available: http://www.citiesalliance.org/ca/sites/citiesalliance.org/files/Anual_Reports/ch-2.pdf.

Development Assistance Committee. (1996) Shaping the 21st Century: The Contribution of Development Cooperation. Paris: Organisation for Economic Co-operation and Development.

Gore, C. (2010) 'The MDG Paradigm, Productive Capacities and the Future of Poverty Reduction', IDS Bulletin 41(1): 70-79.

Fischer, AM. (2010) 'Towards Genuine Universalism within Contemporary Development Policy', IDS Bulletin 41(1): 36-44.

Ford Foundation. (2004) Building Assets to Reduce Poverty and Injustice. New York: Ford Foundation.

Fukuda-Parr, S. (2010) 'Reducing Inequality - The Missing MDG: A Content Review of PRSPs and Bilateral Donor Policy Statements', IDS Bulletin 41(1): 26-35.

Fukuda-Parr, S. (2011) 'Theory and Policy in International Development: Human Development and Capability Approach and the Millennium Development Goals', International Studies Review 13: 122-132.

Hickey, S. and du Toit, A. (2006) 'Adverse-Incorporation, Social Exclusion and Chronic Poverty', Chronic Poverty Research Centre Working Paper 81. Manchester: Chronic Poverty Research Centre, University of Manchester.

Hulme, D. and Moore, K. (2007) 'Assisting the poorest in Bangladesh: Learning from BRAC's 'Targeting the Ultra-Poor' Programme', Brooks World Poverty Institute Working Paper 1. Manchester: Brooks World Poverty Institute, University of Manchester.

Hulme, D. (2009) 'Global Poverty Reduction and the Millennium Development Goals: A Short History of the World's Biggest Promise', Brooks World Poverty Institute Working Paper 100. Manchester: Brooks World Poverty Institute, University of Manchester.

Hulme, D. (2010) 'Lessons from the Making of the MDGs: Human Development Meets ResultsBased Management in an Unfair World', IDS Bulletin 41(1): 15-25. 
Hulme, D. and Scott, D. (2010) 'The Political Economy of the MDGs: Retrospect and Prospect for the World's Biggest Promise', Brooks World Poverty Institute Working Paper 110. Manchester: Brooks World Poverty Institute, University of Manchester.

ILO, International Labour Organisation. (2008) ILO Decent Work Country Programmes: A Guidebook. Geneva: ILO.

Jahan, S. (2010) 'The MDGs Beyond 2015', IDS Bulletin 41(1): 51-59.

Kabeer, N. (2000) 'Social Exclusion, Poverty and Discrimination', IDS Bulletin 31(4): 83-97.

McGregor, A. and Sumner, A. (2010) 'Beyond Business as Usual: What Might 3-D Wellbeing Contribute to MDG Momentum', IDS Bulletin 41(1): 104-112.

Ministry of Cities Brazil. (2004) Cities For All. Brasilia: Ministry of Cities Brazil.

Mitlin, D. (2004) Understanding Urban Poverty Reduction; What Poverty Reduction Strategy Papers Tell Us, IIED Working Paper on Poverty Reduction in Urban Areas, No 13, London.

Moser, CON., ed. (2007) Reducing Global Poverty: The Case of Asset Accumulation. Washington: Brookings Press.

Moser, CON. (2009) Ordinary Families, Extraordinary Lives: Assets and Poverty Reduction in Guayquil, 1978-2004. Washington: Brookings Press.

Moser, CON., A. Norton, A. Stein and Georgieva, S. (2010) Pro-Poor Adaptation to Climate Change in Urban Centres: Case Study of Vulnerability and Resilience in Kenya and Nicaragua. Washington: The World Bank.

Nussbaum, M., Sen, A. (1993) The Quality of Life. Oxford: Oxford University Press.

Poku, N.K. and Whitman, J. (2011) 'The Millennium Development Goals and Development after 2015', Third World Quarterly 32(1): 181-198.

Republic of Benin. (2007) Benin: Poverty Reduction Strategy Paper - Growth Strategy for Poverty Reduction. Washington: International Monetary Fund.

Rockefeller Foundation. (2003) Human Resources for Health and Development: A Joint Learning Initiative. New York: Rockefeller Foundation.

Saith, A. (2006) 'From Universal Values to Millennium Development Goals', Development and Change 37(6): 1167-199.

Satterthwaite, D. (2003) 'The Millennium Development Goals and urban poverty reduction: great expectations and nonsense statistics', Environment and Urbanization 15(2): 179-190. 
Satterthwaite, D. (2006) The Role of Federations Formed by the Urban Poor in Communal Asset Accumulation. Paper presented at the Brookings/Ford Foundation Workshop on Asset-Based $\begin{array}{llllll}\text { Approaches } & (27 & - & 28 & \text { June, } & \text { 2006), }\end{array}$ http://www.brookings.edu/global/assets06/09satterthwaite.pdf.

Sen, A. (1997) 'Editorial: Human Capital and Human Capability', World Development 25(12): 1959-1961.

Sen, A. (1999) Development as Freedom. Oxford: Clarendon Press.

Sherraden, MW. (1991) Assets and the Poor: A New American Welfare Policy. Armonk, NY: M.E. Sharpe.

Sparr, P. and Moser, CON. (2007) 'International NGOs and Poverty Reduction Strategies: The Contribution of an Asset-Based Approach', The Brookings Institution Global Economy and Development Working Paper 8. Washington: The Brookings Institution.

Stein, A. and Vance, I. (2008) 'The role of housing finance in addressing the needs of the urban poor: lessons from Central America', Environment \& Urbanization 20(1): 13-30.

Stein, A. (2010) Urban Poverty, social exclusion and social housing finance: The case of PRODEL in Nicaragua (PhD thesis 7). Lund: Housing Development \& Management, Lund University.

Streeten, P., S.J. Burki, M. ul Haq, N. Hicks and Stewart, F. (1981) First Things First: Meeting Basic Human Needs in Developing Countries. Oxford: Oxford University Press.

Sumner, A. and Tiwari, M. (2009) 'After 2015: What are the Ingredients of an 'MDG-Plus' Agenda for Poverty Reduction', Journal of International Development 21: 834-843.

Thesaurus. (2010) http://thesaurus.com/browse/implicit Accessed on 29 September, 2010.

UDAPE, Unidad de Análisis de Políticas Sociales y Económicas. (2008) Quinto informe de progreso de los Objetivos de Desarrollo del Milenio en Bolivia. La Paz: UDAPE.

UN, United Nations. (2008) Official List of MDG Indicators. United Nations, Available: http://mdgs.un.org/unsd/mdg/Resources/Attach/Indicators/OfficialList2008.pdf.

UN, United Nations. (2010) Keeping the promise: united to achieve the Millennium Development Goals. United Nations, Available: http://www.un.org/en/mdg/summit2010/pdf/mdg\%20outcome\%20document.pdf.

UNDP Benin, United Nations Development Programme Benin. (2008) Rapport sur le Development Humain au Benin 2007/2008. Available: 
http://hdr.undp.org/en/reports/national/africa/benin/nhdr_benin_20072008.pdf

UNDP, United Nations Development Programme. (2010a) The Path To Achieving the Millennium Development Goals: A Synthesis of MDG evidence from around the world. New York: United Nations Development Programme.

UNDP, United Nations Development Programme. (2010b) Beyond The Midpoint: Achieving the Millennium Development Goals. New York: United Nations Development Programme.

UN Millennium Project. (2005) Investing in Development: A Practical Plan to Achieve the Millennium Development Goals (main report). London: Earthscan.

United Republic of Tanzania. (2008) Millennium Development Goals Report: Mid-Way Evaluation 2000-2008. Available: http://www.tz.undp.org/docs/MDGprogressreport.pdf

Vandemoortele, J. (2011) 'If not the Millennium Development Goals, then what?', Third World Quarterly 32(1): 9-25.

World Bank. 2001. World Development Report 2000/2001: Attacking Poverty. Oxford University Press, Oxford. 